Syntax Literate : Jurnal Ilmiah Indonesia p-ISSN: 2541-0849

e-ISSN : 2548-1398

Vol. 5, No. 1 Januari 2020

\title{
PENGARUH PEMBERIAN ZINC, FE DAN VITAMIN A TERHADAP KEJADIAN INFEKSI DAN PERTUMBUHAN
}

\author{
Ignatius Hapsoro Wirandoko dan Ruri Eka Maryam Mulyaningsih \\ Universitas Swadaya Gunung Jati Cirebon \\ Email: ignatiushapsorowirandoko@gmail.com dan ruriade@gmail.com
}

\begin{abstract}
Abstrak
Kekurangan zat zinc dapat mengganggu pertumbuhan dan meningkatkan resiko mendapat diare dan infeksi saluran nafas. Suplementasi zinc dan besi mungkin meningkatkan pertumbuhan anak. Defisiensi vitamin A dapat menyebabkan kebutaan pada anak usia dini, sehingga menghambat tumbuh kembang anak.Membuktikan efek pemberian zinc, fe, dan vitamin A dalam menurunkan kejadian infeksi dan memperbaiki pertumbuhan pada anak gizi kurang usia 2-5 tahun. Pre $n$ post test. Satu bulan sebelum diintervensi pengambilan sampel darah kadar Zink,Fe dan Vitamin A, ditanyakan kejadian infeksi (berapa kali dalam 1 bulan terakhir) dan pertumbuhan TB di lihat di KMS. Satu bulan setelah diintervensi diambil sampel darah lagi kadar Zink,Fe, dan Vitamin A, ditanyakan lagi pertumbuhan dan kejadian infeksi. Sebelum Penelitian dilakukan sidang Komisi Etik oleh Tim Komisi Etik Fakultas Kedokteran Unswagati Cirebon (Full Board). Intake vitamin A ( $\mu \mathrm{g})$ rata-rata $303 \pm 11$ dan untuk intake zat besi rata-rata $5,74 \pm 0,3 \mathrm{mg}$, sedangkan intake zink rata-rata 3,8 \pm 0 . Bila dibandingkan dengan Angka Kecukupan Gizi (AKG) maka intake vitamin A, zat besi dan zink secara rata-

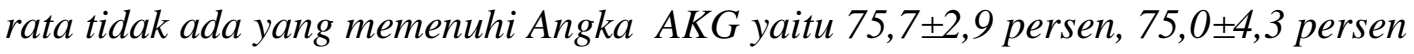
dan 47,4 $\pm 1,8$ persen. Indikator Tinggi Badan/ Umur (TB/U) banyak anak dengan stunting sebesar 15,9 persen, sedangkan anak dengan obese indikator berat badan/tinggi badan (BB/TB) sebesar 1 persen. Keadaan kesehatan sampel penelitian ditemukan lebih dari separuh sampel menderita Infeksi Saluran Pernafasan Akut (ISPA) 60,4 persen dan diare 21,3 persen diare. Intake makanan zat besi, zink dan vitamin A anak 24-60 bulan di Indonesia masih tidak dapat memenuhi kebutuhan dan jauh di bawah Angka Kecukupan Gizi (AKG). Faktor yang secara konsisten berpengaruh terhadap pemenuhan kebutuhan mikronutrien tersebut (zat besi, zink, vitamin A) dan status sosial ekonomi rendah.
\end{abstract}

Kata kunci: Zinc, Fe, Vitamin A, Infeksi dan Pertumbuhan

\section{Pendahuluan}

Suatu asumsi yang selama ini berkembang adalah bahwa penyebab anemia satusatunya adalah kekurangan zat besi dan dapat dengan mudah diobati dengan suplementasi. Padahal penyebab anemia ada beberapa yaitu infeksi, kekurangan vitamin A, infestasi kecacingan, dan hemoglobinopati. Hal ini juga menjelaskan bahwa tidak semua yang kekurangan zat besi menderita anemia. 
Anemia merupakan suatu kondisi klinis penurunan kuantitas sel-sel darah merah dalam sirkulasi yang ditandai dengan rendahnya kadar hemoglobin dalam darah (Bakta: 2006). Penurunan jumlah hemoglobin dalam darah akan menyebabkan penurunan kadar oksigen yang dibawa oleh sel darah merah sehingga menyebabkan penurunan pasokan oksigen pada organ tubuh (Muis \& Anjani, 2017).

Kelirunya asumsi tersebut menjadi penyebab kegagalan utama dari proyek kesehatan yang dibiayai UNICEF untuk mengurangi penderita anemia. Walaupun suplementasi dan fortifikasi zat besi adalah strategi paling efektif, perlu juga diperhitungkan kerumitan masalah ini agar tingkat keberhasilan sebuah intervensi dapat dengan tepat diintervensikan dan dievaluasi (Min Kyaw Htet, 2011).

Kekurangan mikronutrien sering terjadi pada anak - anak khususnya usia 2-5 tahun. Kekurangan zat besi dapat memberi pengaruh yang buruk terhadap perkembangan mental dan motorik anak. Kekurangan zat zinc dapat mengganggu pertumbuhan dan meningkatkan resiko mendapat diare dan infeksi saluran nafas. Suplementasi zinc dan besi mungkin meningkatkan pertumbuhan anak. Defisiensi vitamin A dapat menyebabkan kebutaan pada anak usia dini, sehingga menghambat tumbuh kembang anak.

Definisi besi dapat menggangu perkembangan perkembangan mental dan motorik anak (Nasution, 2004). Defisiensi zinc juga dapat mengganggu pertumbuhan (Brown, Bildsten, \& Rutledge, 1998) dan meningkat resiko diare dan infeksi saluran nafas (Ninh et al., 1996).

Suatu penelitian dilakukan di Brasil menunjukan suplementasi zinc $5 \mathrm{mg}$ dapat menurunkan frekuensi diare pada bayi dengan berat badan lahir rendah. Studi yang dilakukan oleh (P. Singh Fahmida Aktar, Majajul Alam Sarker, O, 2001) mengenai suplementasi besi $10 \mathrm{mg} / \mathrm{hari}$ dan zinc $10 \mathrm{mg} / \mathrm{hari}$ pada bayi, ternyata mempunyai efek yang positif terhadap tinggi badan.

Studi di Indramayu (Kamiya, Tanaka, Endang, Umar, \& Satake, 2004) menunjukan bayi pada anak pendek menurut umur yang diberi suplementasi zinc ditambah besi selama 24 minggu dapat meningkatkan panjang bayi namun tidak terjadi peningkatan berat badan.

Temuan laboratorium didapatkan indeks eritrosit sudah menurun dan penurunannya terjadi secara progresif sejalan dengan memberatnya anemia. Sediaan hapus darah menunjukan sel mikrositik hipokrom dan kadang - kadang ditemukan sel target dan poikilosit berbentuk pensil. Hitung retikulosit rendah jika dibandingkan dengan derajat anemia. Besi serum dan daya ikat besi total meningkat (TIBC) sehingga TIBC kurang dari $10 \%$ tersaturasi.

Absorpsi besi dari makanan sebagian diabsorpsi sebagai heme dan sebagian dipecah dalam usus menjadi besi anorganik (Kamiya et al., 2004). Absorpsi terjadi melalui duodenum dan dibantu oleh faktor-faktor seperti asam dan zat pereduksi yang mempertahankan besi di lumen usus dalam keadaan $\mathrm{Fe} 2+$ dan bukan $\mathrm{Fe} 3+$.

Protein DMT-1 (Divalent Metal Transporter) terlibat dalam pengangkutan besi dari lumen usus melalui mikrovilus enterosit. Feroportin pada permukaan basolateral 
mengatur keluarnya besi dari sel ke dalam plasma porta. Besi dimasukkan ke dalam enterosit kriptus dari transferin plasma yang berikatan dengan reseptor transferin sehubungan dengan protein HFE pada permukaan basal sel. Pada defisiensi besi, lebih sedikit besi yang dibawa ke sel kriptus dari transferin yang sebagian besar tidak terjenuhkan oleh besi.

\section{Metode Penelitian}

Pre $\mathrm{n}$ post test

- Satu bulan sebelum diintervensi pengambilan sampel darah kadar Zink,Fe dan Vitamin A, ditanyakan kejadian infeksi (berapa kali dalam 1 bulan terakhir) dan pertumbuhan TB di lihat di KMS.

- Satu bulan setelah diintervensi diambil sampel darah lagi kadar Zink,Fe, dan Vitamin A, ditanyakan lagi pertumbuhan dan kejadian infeksi.

\section{Hasil dan Pembahasan}

Hasil penelitian yang dilakukan SEANUTS menggambarkan lebih dari setengah dari anak yang berpartisipasi sebagai sampel, mempunyai asupan dibawah Angka Kecukupan Gizi (AKG) Indonesia. Saat ini Indonesia masih mengalami masalah gizi ganda dimana prevalensi tinggi pada stunting dan berat badan kurang serta prevalensi yang tinggi dari anemia zat gizi besi pada anak dibawah umur 2 tahun (World Health Organization. Vitamin A supplementation in infants and children 6-59-months of age, 2011).

Stunting menurut WHO adalah kurangnya pertumbuhan tinggi badan menurut umur. Hal ini mengindikasikan suatu keadaan kronis kurang gizi, serta merupakan hasil dari kekurangan asupan makanan dalam waktu lama, kurang berkualitasnya makanan, keadaan kesakitan yang meningkat (sering sakit) atau gabungan dari kedua faktor tersebut.

Penelitian yang dilakukan oleh Shakur, 2012 menyatakan bahwa diet saja prevalensi untuk pemenuhan zat gizi rendah kecuali untuk kalsium, magnesium, vitamin A dan D.

Hasil penelitian SEANUTS tentang pola makan anak berumur 6 - 23 bulan memberikan gambaran bahwa konsumsi daging, ikan dan unggas jarang dikonsumsi bahkan sebagian besar tidak atau belum pernah mengkonsumsi. Pola makan seperti ini mengakibatkan tidak terpenuhinya asupan zat besi, vitamin A dan zink sehingga persen AKG nya rendah.

\section{Kesimpulan}

Intake makanan zat besi, zink dan vitamin A anak 24-60 bulan di Indonesia masih tidak dapat memenuhi kebutuhan dan jauh di bawah Angka Kecukupan Gizi (AKG). Faktor yang secara konsisten berpengaruh terhadap pemenuhan kebutuhan mikronutrien tersebut (zat besi, zink, vitamin A) dan status sosial ekonomi rendah. 
Ignatius Hapsoro Wirandoko dan Ruri Eka Maryam Mulyaningsih

\section{BIBLIOGRAFI}

Brown, E. F., Bildsten, L., \& Rutledge, R. E. (1998). Crustal heating and quiescent emission from transiently accreting neutron stars. The Astrophysical Journal Letters, 504(2), L95.

Kamiya, K., Tanaka, Y., Endang, H., Umar, M., \& Satake, T. (2004). Chemical constituents of Morinda citrifolia fruits inhibit copper-induced low-density lipoprotein oxidation. Journal of Agricultural and Food Chemistry, 52(19), 58435848.

Muis, S. F., \& Anjani, G. (2017). Status Gizi Dan Tingkat Kecukupan Zat Gizi Pada Remaja Putri Anemia. Syntax Literate; Jurnal Ilmiah Indonesia, 2(12), 1-8.

Nasution, E. (2004). Efek suplementasi zinc dan besi pada pertumbuhan anak.

Ninh, N. X., Thissen, J.-P., Collette, L., Gerard, G., Khoi, H. H., \& Ketelslegers, J.-M. (1996). Zinc supplementation increases growth and circulating insulin-like growth factor I (IGF-I) in growth-retarded Vietnamese children. The American Journal of Clinical Nutrition, 63(4), 514-519.

P. Singh Fahmida Aktar, Majajul Alam Sarker, O, T. M. A. K. (2001). Recent sea level and sea surface temperature changes along the Maldives coast. Marine Geodesy, 24(4), 209-218.

World Health Organization. Vitamin A supplementation in infants and children 6- 59months of age. (2011). Geneve. 